\title{
Factors Influencing Intentions to Use Cardless Automatic Teller Machine (ATM)
}

\author{
Submitted 12/04/19, $1^{\text {st }}$ revision $19 / 05 / 20,2^{\text {nd }}$ revision $15 / 06 / 20$, accepted $20 / 07 / 20$
}

\section{Kitti Phothikitti ${ }^{1}$}

\begin{abstract}
:
Purpose: The purpose of this study is to determine the key factors that determine usage intention towards cardless Automatic Teller Machine (ATM) among customers, as a new way to withdraw transactions. Perceived usefulness, perceive ease of use and Amount of information are proposed to have strong influences towards usage intention.

Design/Methodology/Approach: The researcher conducted the study based on a quantitative approach and conducted a nonprobability sampling method as part of a convenience sampling method. The questionnaire was developed and distributed through online channels to the target respondents. The data were collected from 400 respondents only Thai bank customers who normally withdrawn cash via Automatic Teller Machine (ATM) but never had experience with cardless ATM service. This study applied Structural Equation Model (SEM) and Confirmatory Factor Analysis (CFA) to examine the model accuracy and reliability and verify influence of various variables.

Findings: The results indicated that perceived usefulness, perceived ease of use and the amount of information have positive significant influence on usage intention towards Cardless ATM. The results also indicated that perceived ease of use has significant influence on perceive usefulness.

Practical Implications: This study has certain boundaries that must be explored to further study including many respondents not having enough information of the service, next whether there is a small number of independent variable to measure in this study and the last is moderation is not present in this study.

Originality/Value: This study provides important information for practitioners (i.e. banks), academicians (i.e. lecturers) and bank customers.
\end{abstract}

Keywords: Cardless Automatic Teller Machine (ATM), mobile banking, perceive ease of use, perceive usefulness, perceive credibility.

JEL Code: M15, M31.

Paper Type: Research article.

${ }^{1}$ Ph.D., Lecturer of Graduate School of Business, Assumption University of Thailand, e-mail: kittipht@au.edu; 


\section{Introduction}

In 2017, Government Savings Bank have launched cardless (ATM services through a mobile banking application on a smartphone, which is the first bank in Thailand and nowadays there are total 6 financial institutions in Thailand that have provided cardless ATM services including Siam Commercial Bank, Kasikorn Bank, TMB Bank, Krungsri Bank, Government Saving Bank and Krungthai Bank (Bangkok Post, 2019a).

The "Cardless" ATM is the new technology service that offers an ultimate convenience to the consumers, with smartphone technology allowing consumers to make cash withdrawals from their own account using a simple mobile application instead of Automatic teller Machine or debit cards. When you want to make a withdrawal at a cardless ATM, the app can produce some sort of authentication key, such as scanning a QR code for the ATM or a numeric code that you can punch in. Once you enter the check key and your Password, the ATM will process the transaction and dispense your cash without inserting a physical bank card.

Most financial institutions see Cardless ATM as a way of enhancing customer service through this technology, helping consumers withdraw cash faster and more efficiently, as well as saving transaction costs. The benefits of this feature in term of cost reduction are that the customers do not need to pay for card fee anymore and it is free of charge when withdrawing a cash from the ATM that the bank has provided.

Compared to debit cards and ATM cards, the customer will need to pay for service charge of at least 200 baht per year and the customer will be charged when they withdraw cash from the same bank across provinces or withdraw from a difference bank from the same province or up-country in which the rate is different as per each bank and transactions (Bangkok Post, 2019a). Another, benefit of this technology is to reduce the time spent at the ATM to about 10 seconds instead of the typical 30 to 40 seconds (Bangkok Post, 2019b) by inserting the ATM cards inside the ATM machines. Moreover, customers don't have to worry about losing your card or forgetting your PIN.

The number of using mobile banking in Thailand has increased continuously and now Thais use the world's number 1 mobile banking constituting $74 \%$ of all internet users in the country use Mobile Banking. In year 2019 the number of mobile banking users in Thailand stands at 41 Million accounts and in third quarter of year 2019 has increased to 56 Million accounts (Bangkok Post, 2019b).

As a result of the benefits that mention above with number of mobile banking users are increasing. This leads to an empirical study of factors influences intention to use cardless ATM. In addition, this research will be beneficial to banks in learning about customer behavior and the reasons behind adopting cardless ATM services. 


\section{Literature Review}

\subsection{Perceived Usefulness and Usage Intentions}

The importance of perceived usefulness was commonly known in the area of EBanking (Guriting and Ndubisi, 2006). According to the researchers perceive usefulness is the subjective probability that using technology would improve the way of a user to complete a given performance. Davis (1989) defined Perceived Usefulness as the level to which a person believed that using the technology will improve his or her task. In the same way, Mathwick et al. (2001) determined perceived usefulness as the extent to which individual deems a particular system can increase the efficiency of his or her task. For the meaning of intention to use is user's ability to make or support a decision according to their wishes (Davis, 1986; Wu and Wang, 2008). In the same way Fishbein and Ajzen's (1975) defined intention to use in terms of behavioral strength of a person who intend to conduct a specified behavior.

According to Davis et al. (1992), there are high associations between perceive usefulness and intention to use technology. There are extensive research that discovered that perceived usefulness has influence on mobile banking usage intention (Davis, 1989; Venkatesh et al., 2012). Wang et al. (2003) found that there is a positive relationship between perceived usefulness and behavioral intention to use mobile banking and in 2000, Venkatesh (2000) claimed that customers will have the intention to use mobile banking once customers perceive usefulness in technology. Moreover, Cheong and Park (2005) discovered that perceived usefulness has positive effect on usage intentions towards mobile internet. Thus, the opportunities of continuing to use cardless ATM will be increase if the customers perceive a proper use of it (Hussein Al-Fahim, 2012).

\subsection{Perceived Ease of Use}

Davis (1989) mentioned that one factor that drives the acceptance of new systems is termed as 'perceived ease of use' which is the concept that use Information Technology (IT), is related to the person's assessment of the rational effort (Venkatesh, 2000). Few researches defined the meaning of Perceived ease of use as the degree to which a person believes that he or she can use the technology without difficulty and other endeavors (Davis, 1989). From the context of this study, Peou (XXXX) refers to user's belief that they can use Cardless ATM without any endeavors. In reference to Davis's study (1989) that claimed the factor that influences customers to use the system, which is ease of use, if the systems are convenient and user friendly, customers will intend to use it. Previous studies revealed that perceived ease of use and the intention to adopt mobile banking have a relationship in positive ways (Marsh et al., 2004; Alalwan et al., 2017; Guriting and Ndubisi, 2006; Wang et al., 2006). The easier the system is for customer's use, the more likely in customers' intention to continue using cardless ATM will be 
(Kesharwani and Bisht, 2012). Similarly, in year 2016, Alalwan et al. (2017) argued that ease of use has positive affect on usage intention of internet mobile banking. In addition, Davis et al. (1989) proposed that perceived ease of use comes first and perceived usefulness comes later, the evidence from IS literature revealed that the greater perceived ease of use of any device results in greater perceived usefulness (Elkhani, Soltani and Ahmad, 2014). Moreover, previous research showed that perceived ease of use has significant effect on perceived usefulness in adoption of technological products and services (Kleijnen et al., 2004; Wang et al., 2003; Davis, 1993).

\subsection{Perceived Credibility}

There are two important dimensions that are related to perceived credibility for instance security and privacy (Wang et al., 2003). Ajren (2002) highlighted perceived credibility from the context of Mobile banking as the judgment on privacy and security of individual issues with the cardless ATM system. Moreover, Wang et al. (2003) explained the meaning of perceive credibility that there is no security and privacy threat to user who uses cardless ATM system. Furthermore, Wang et al. (2003) found that there is a significance between perceived credibility towards technology acceptance of internet banking. In year 2005, Luarn and Lin (2004) also identified that perceived credibility and intention to use mobile banking have a positive causal relationship. Furthermore, the significance of security and privacy towards the acceptance of banking technologies has been widely used in the banking studies (Howcroft et al., 2002; Pikkarainen et al., 2004; Sathye, 1999).

\subsection{The Amount of Information on Cardless Withdrawal}

The amount of information is one of the factors that influence customers using cardless ATM. If a person has enough information on cardless ATM, the possibility to adopt to this technology will be higher. There are many researches in the past that has shown the evidence of significant impact between new technological information and usage intentions (Pikkarainen et al., 2004; Sathye, 1999; Howard and Moore, 1982; Drewniak and Posadzińska, 2020). Sathye (1999) argued that low awareness of mobile banking is an important factor that lead people not to show interest in mobile banking due to lack of knowledge and understanding of the program's structure. Howard and Moore (1982) revealed that consumers will adapt to the new product when they are aware of it. Moreover, Pikkarainen et al. (2004) found bank customer's knowledge has a positive impact on online banking acceptance. Therefore, cardless ATM acceptance also depends on the amount of information that bank provides to its customers.

\section{Research Framework}

The research model shown in Figure 1 is adapted from the theoretical framework from a research on mobile credit card usage intentions (Ajren and Fishbein, 1980). 
44

This research framework was aimed to identify the factors that have significant influence on cardless ATM usage intentions which are perceived usefulness, perceived ease of use, perceived creditability and the amount of information on cardless ATM. The study also aims to indicate that there is a significant relationship between perceived ease of use and perceived usefulness.

Figure 1. Conceptual Framework

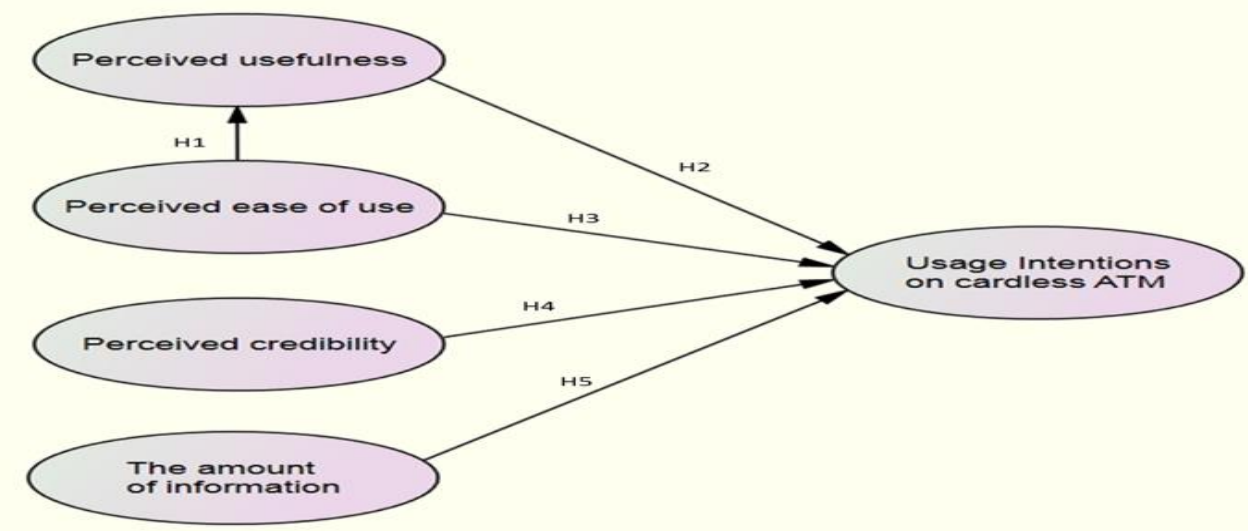

Source: Author.

Total five hypotheses are available in this study in order to accomplish the research objectives, as shown in Table 1. The hypotheses are defined to align with the conceptual framework as followed.

Table 1. Research Hypotheses

\begin{tabular}{|c|c|l|}
\hline No. & H & \multicolumn{1}{|c|}{ Hypotheses } \\
\hline 1 & H1 & Perceived ease of use significantly influence on perceived usefulness. \\
\hline 2 & H2 & $\begin{array}{l}\text { Perceived usefulness significantly influence on cardless automatic teller } \\
\text { machine (ATM) usage Intentions }\end{array}$ \\
\hline 3 & H3 & $\begin{array}{l}\text { Perceived ease of use significantly influence on cardless automatic teller } \\
\text { machine (ATM) usage Intentions }\end{array}$ \\
\hline 4 & H4 & $\begin{array}{l}\text { Perceived credibility significantly influence on cardless automatic teller } \\
\text { machine (ATM) usage Intentions }\end{array}$ \\
\hline 5 & H5 & $\begin{array}{l}\text { The amount of information significantly influence on cardless automatic } \\
\text { teller machine (ATM) usage Intentions }\end{array}$ \\
\hline
\end{tabular}

Source: Author.

\section{Research Methodology}

For this research, the researcher used the quantitative method to gather data from the respondents. The questionnaire was created online and distributed via Facebook, Line and share between Friends and other related group of people. The target 
respondent in this research are Thai bank customers who normally withdrawn cash via ATM but never had experience with cardless ATM service. The data were collected from target respondents to examine the factors influencing usage intention of cardless ATM. There are 3 parts in this questionnaire. Firstly, the screening questions were proposed to sort respondents who are Thai bank customers who normally withdrawn cash via ATM but never had experience with cardless ATM. Next part is a five-point Likert scale which is used to measure a difference ranging scale from strongly disagree (1) to strongly agree (5). Lastly, the demographic questions are used to collect the respondent's information such as gender, age, income level and mobile banking using experience.

Based on the pilot test, the questionnaires were given to 30 target group. The Cronbach alpha analysis was used in this research to verify the reliability and make sure that the questionnaire was accurate. After passing the pilot test, the questionnaires were distributed again to 400 target respondents via online channels. SPSS 24 and AMOS 18.0 were used in this study to analyse the collected data. To test the convergence validity and discriminant validation results, Confirmatory Factor Analysis (CFA) was applied in this study. The measurement model fit was evaluated to test the data fit and confirm the validity and reliability of the model. Finally, the Structural Equation Model (SEM) was applied to examine the influences between independent and dependent variables.

\subsection{Population and Sample Size}

The target respondents of this research are Thai bank customers who normally withdrawn cash via ATM but never had experience with cardless ATM service. With reference to A-priori Sample Size Calculator for Structural Equation Models (SEM) from danielsoper's website by setting the number of observed and latent variables in the model, there were about 5 latent variables, 16 observed variables with a probability level at 0.05 . The calculated result showed that the recommended minimum sample size to detect the effect is for 400 respondents. The total number of respondents who participated in the survey was 468 from various demographic profiles. After screening the surveys, there are about 400 respondents who are qualified to be used in this study. Therefore, the researcher used 400 respondents to analyze the study.

\subsection{Sampling Technique}

The online questionnaire survey was conducted using non-probability sampling methods with convenience techniques to gather data from 400 target group. The researcher distributed the questionnaires randomly via online channels such as Google, Facebook, Line and E-mail to the respondents who are conveniently eligible to participate in this study. Thus, using this technique is easy to access and proximate the researchers to reach to their target respondents because the researchers can share a link of the online questionnaire survey to respondents and these people can share 
the questionnaire to their friends, family or workmates who also have the characteristics needed to be a part of the target respondents. Thus, the convenience sampling approach is the most effective and easiest way to collect primary data sources used in this analysis (Suhr, 2006).

\subsection{Pilot Test}

To investigate the questionnaire's reliability, a pilot test was conducted with 30 respondents by using Cronbach's Alpha Coefficient before official launch. For the standard of Cronbach's Alpha Coefficient is more than 0.7 derived from the reference in Table 2, the Cronbach's Alpha Coefficient falls in a range in between 0.700 to 0.887 that is more than 0.7 , which shows that the questionnaire is reliable and all questions for each variable are valid. Therefore, the questionnaires developed for this study is acceptable to continue for the research. (Tavakol and Dennish, 2011).

Table 2. Result of Cronbach's Alpha Reliability Test $(N=30)$

\begin{tabular}{|l|c|c|}
\hline \multicolumn{1}{|c|}{ Variable Name/(Source of Measurement Items) } & Cronbach's $\boldsymbol{\alpha}$ & Number of Items \\
\hline Perceived Usefulness (PU) / (Davis, 1989) & 0.700 & 4 \\
\hline Perceived Ease of Use (PE) / (Davis, 1989) & 0.723 & 4 \\
\hline Perceived Credibility (PC) / (Davis, 1989) & 0.887 & 2 \\
\hline $\begin{array}{l}\text { The Amount of Information (AIM) } \\
\text { (Pikkarainen et al., 2004) }\end{array}$ & 0.883 & 3 \\
\hline Usage Intention (USIT) / (Davis, 1989) & 0.815 & 3 \\
\hline
\end{tabular}

Source: Author.

\section{Results and Discussion}

\subsection{Demographics}

The target respondents are Thai bank customers who normally withdrawn cash via ATM but never had experience with cardless ATM service. The demographic profile is summarized and shown in Table 3.

The sample consists of 400 valid respondents; the majority of gender respondents in this study were female representing $78.8 \%$ while the male respondents representing only $21.3 \%$ of the respondents. In terms of respondent's age, there are 18-24 years, 25-30 years, 31-35 years, 36-40 years, 41-45 years, and above 40 years, with a percentage of $2 \%, 47.8 \%, 36.3 \%, 8.8 \%, 4.3 \%$ and $1 \%$ respectively. As part of income level, the highest income range of the target respondents are 20,001-30,000 THB representing 37\% followed by Less than 20,000 THB representing 30.3\%, $30,001-40,000$ THB representing 22.3\%, 40,001-50,000 THB in 7.5\% and more than 50,000 Baht at only $3 \%$ of the respondents. 
For frequency of money withdrawals in each month, the mainly is 3 to 6 times a month representing $43.5 \%$, followed by less than 3 times a month representing $41.8 \%, 7$ to 10 times a month for $12.5 \%$ and more than 10 times a month representing $2.3 \%$ of the respondents. Therefore, majority of the respondents comprising $98.8 \%$ are using mobile banking application while only $1.3 \%$ are not using the mobile banking application.

Table 3. Demographic Profile

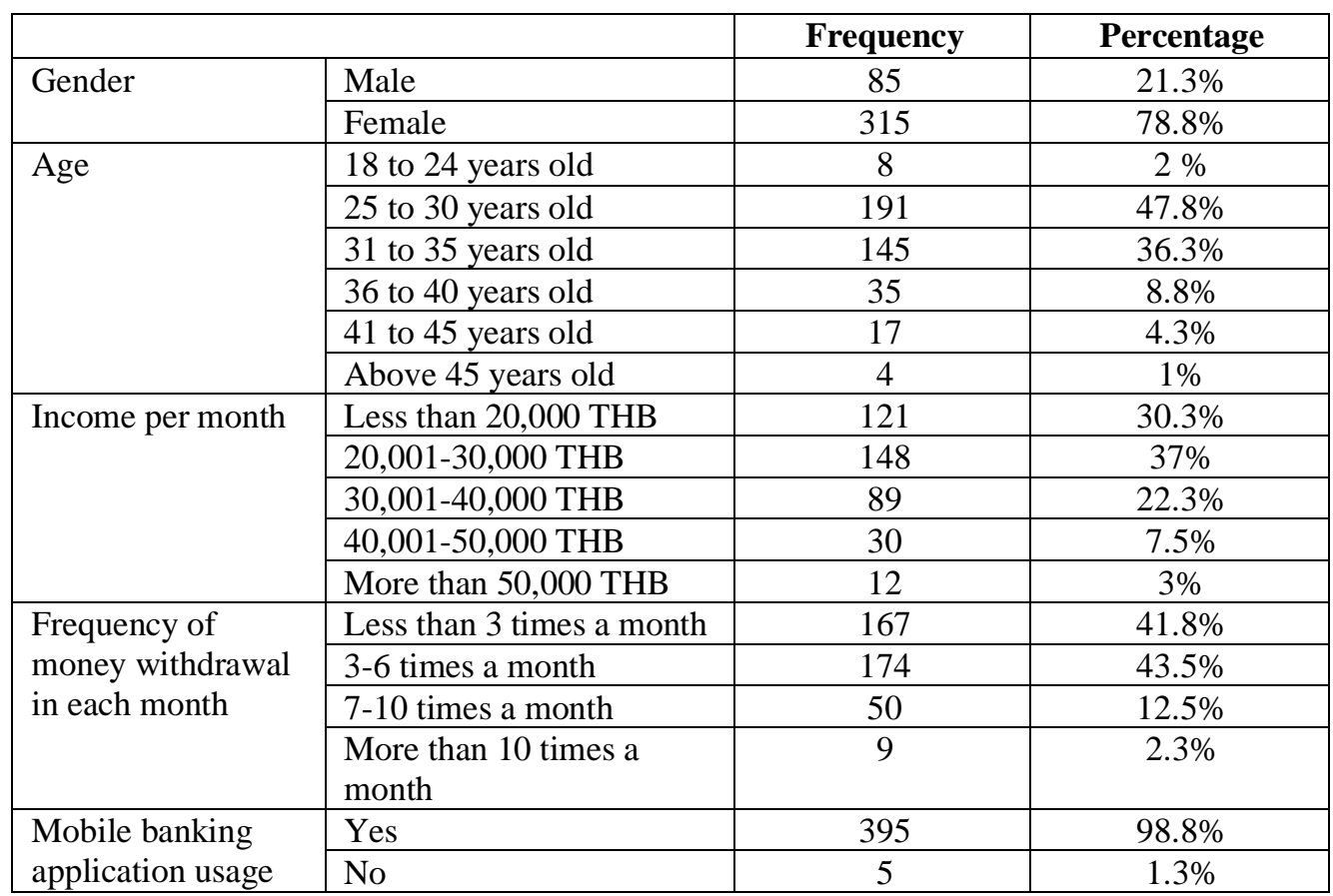

Source: Author.

\subsection{Confirmatory Factor Analysis (CFA)}

In statistics, confirmatory factor analysis (CFA) is a multivariate statistical procedure that is used to verify the factor structure of a set of observed variables by testing the hypothesis that have relationship between the manifest variables and their underlying latent existing construct (Suhr, 2006). Confirmatory Factor Analysis (CFA) can check the results of the factor loading, Composite Reliability (CR) and Average Variance Extracted (AVE). According to theory (Kline, 1994) that the factor loading must be over than 0.3 . The result is considered appropriate when CR $\alpha>0.7$ due to the reliability was approximated by the Composite Reliability (CR) and standardized Cronbach's coefficient alpha $(\alpha)$, Lastly, the Average Variance Extracted (AVE) was applied to assess the convergent validity and acceptable values (AVE>0.5) are clarifying the factor's convergent validity as displayed in Table 4. 
To test the correlation between variables, the discriminant validity is evaluated by calculating the square root of the Average Variance Extracted (AVE). The value of discriminant validity normally should be above all inter-construct/factor correlations. Therefore, this can be confirmed that the discriminant validity is considered to be supportable as shown in Table 5. As shown in Table 6, the confirmatory factor analysis showed a reasonable data fit to the measurement model of six variables. All indices were larger than the suggestion of criteria.

Table 4. Confirmatory factor analysis results, Composite Reliability (CR) and Average Variance Extracted (AVE)

\begin{tabular}{|l|c|c|c|c|c|}
\hline \multicolumn{1}{|c|}{ Variables } & Factor Loading & S.E. & T-value & CR & AVE \\
\hline Perceived Usefulness (PU) & & & & 0.906 & 0.707 \\
PU 1 & 0.853 & & & & \\
PU 2 & 0.813 & 0.046 & $23.541^{* * *}$ & & \\
PU 3 & 0.853 & 0.048 & $21.111^{* * *}$ & & \\
PU 4 & 0.844 & 0.050 & $21.067^{* * *}$ & & \\
\hline Perceived Ease of Use (PE) & 0.868 & & & 0.914 & 0.726 \\
PE 1 & 0.808 & 0.050 & $20.140^{* * *}$ & & \\
PE 2 & 0.881 & 0.046 & $23.494^{* * * *}$ & & \\
PE 3 & 0.850 & 0.045 & $22.193^{* * * *}$ & & \\
PE 4 & 0.941 & & & 0.885 & 0.794 \\
Perceived Credibility (PC ) & 0.838 & 0.049 & $18.035^{* * * *}$ & & \\
PC1 & & & & 0.894 & 0.737 \\
PC2 & 0.853 & & & & \\
\hline The Amount Of Information (AIM) & 0.885 & 0.045 & $22.352^{* * * *}$ & & \\
AIM 1 & 0.837 & 0.048 & $20.835^{* * * *}$ & & \\
AIM 2 & & & & 0.883 & 0.716 \\
AIM 3 & 0.859 & & & & \\
\hline Usage Intention (USINT) & 0.909 & 0.048 & $22.467 * * *$ & & \\
USINT 1 & 0.764 & 0.049 & $18.146^{* * * *}$ & & \\
USINT 2 & & & & \\
USINT 3 & & & & \\
\hline
\end{tabular}

Note: $C R=$ Composite Reliability, $A V E=$ Average Variance Extracted $* * *=$ Significant at the 0.05 significant levels $(p<0.05)$

Source: Author.

Table 5. Discriminant Validity

\begin{tabular}{|l|r|r|r|r|r|}
\hline & \multicolumn{1}{|c|}{ PU } & \multicolumn{1}{c|}{ PE } & \multicolumn{1}{c|}{ PC } & \multicolumn{1}{c|}{ AIM } & \multicolumn{1}{c|}{ USINT } \\
\hline PU & $\mathbf{. 8 4 1}$ & & & & \\
\hline PE & .536 & $\mathbf{. 8 5 2}$ & & & \\
\hline PC & .437 & .424 & $\mathbf{. 8 9 1}$ & & \\
\hline AIM & .413 & .393 & .535 & $\mathbf{. 8 5 9}$ & \\
\hline USINT & .574 & .483 & .470 & .478 & $\mathbf{. 8 4 6}$ \\
\hline
\end{tabular}

Note: The diagonally listed values are the AVE square roots of the variables

Source: Author. 
Table 6. Goodness of Fit

\begin{tabular}{|l|l|c|}
\hline Index & Criteria & Result of this study \\
\hline CMIN/DF & $<3.00$ (Hair et al., 2006) & 1.928 \\
\hline GFI & $\geq 0.90$ (Hair et al., 2010) & 0.956 \\
\hline AGFI & $\geq 0.85$ & 0.922 \\
\hline NFI & $\geq 0.90$ & 0.928 \\
\hline CFI & $\geq 0.90$ (Hair et al., 2006) & 0.986 \\
\hline TLI & $\geq 0.90$ (Hu and Betler, 1999; Marsh, Hau and & 0.978 \\
\hline RMSEA & Wen, 2004) & 0.05 (Browne and Cudeck, 1993) \\
\hline RMR & $<0.05$ (Hair et al., 2006) & 0.019 \\
\hline
\end{tabular}

Note: $C M I N / D F=$ The ratio of the chi-square value to degree of freedom, GFI = goodnessof-fit index, $A G F I=$ adjusted goodness-of-fit index, NFI, normalized fit index, TLI = TuckerLewis index, $C F I=$ comparative fit index, RMSEA = root mean square error of approximation, and $R M R=$ root mean square residual

Source: Author.

\subsection{Structural Equation Model (SEM)}

The Structural Equation Modeling (SEM) is used to check the hypothesis and to evaluate the relationships between constructs in the model. Subsequent of process in SEMs and adjust the model, the results showed that the overall model fit index are $\mathrm{CMIN} / \mathrm{DF}=1.809, \mathrm{GFI}=0.961, \mathrm{AGFI}=0.930, \mathrm{NFI}=0.973, \mathrm{CFI}=0.988, \mathrm{TLI}=$ 0.980, RMSEA $=0.045$ and $\mathrm{RMR}=0.017$ according to the measurable criterias those are mentioned in Table 6.

\subsection{Research Hypothesis Testing Results}

The results of hypothesized test are shown in Table 7 which summarize that $\mathrm{H} 1, \mathrm{H} 2$, $\mathrm{H} 3$ and $\mathrm{H} 5$ are supported but $\mathrm{H} 4$ is not supported.

Table 7. Hypotheses Results of the Structural Model

\begin{tabular}{|l|c|c|c|}
\hline \multicolumn{1}{|c|}{ Hypotheses } & $\begin{array}{c}\text { Standardized Path } \\
\text { Coefficients }\end{array}$ & T-Value & Results \\
\hline $\begin{array}{l}\text { H1: Perceived Ease of Use => Perceived } \\
\text { Usefulness }\end{array}$ & .563 & $10.916^{* * *}$ & Supported \\
\hline $\begin{array}{l}\text { H2: Perceived Usefulness => Usage } \\
\text { Intentions }\end{array}$ & .371 & $6.464^{* * *}$ & Supported \\
\hline $\begin{array}{l}\text { H3: Perceived Ease of Use => Usage } \\
\text { Intentions }\end{array}$ & .218 & $3.876^{* * * *}$ & Supported \\
\hline $\begin{array}{l}\text { H4: Perceived Credibility => Usage } \\
\text { Intentions }\end{array}$ & .059 & .970 & $\begin{array}{c}\text { Not } \\
\text { Supported }\end{array}$ \\
\hline
\end{tabular}




\begin{tabular}{|l|l|l|l|}
\hline $\begin{array}{l}\text { H5: The amount of Information => Usage } \\
\text { Intentions }\end{array}$ & .252 & $4.298 * * *$ & Supported \\
\hline
\end{tabular}

Note: $* * * p<0.001, * * p<0.01$ and $* p<0.05$

Source: Author.

H1: The standardized path coefficient between perceived ease of use and perceived usefulness was 0.563 at t-value equals to $10.916^{* * *}$. Perceived ease of use has significantly influence on perceived usefulness. Therefore, $\mathrm{H} 1$ was supported. It can be concluded that if people think that the system is user-friendly, their inner-self feel that the system is useful for them. As a result, the easier in system is for customer's use, the more likely in customers' intention to continue using cardless ATM. This set of findings is aligned with previous studies conducted by Elkhani, Soltani and Ahmad (2014).

H2: The standardized path coefficient between perceived usefulness and usage intentions was 0.371 at t-value equals to $6.464 * * *$. Perceived ease of use has significantly influence on usage Intentions. Thus, H2 was supported. The result explained that when people perceive that the technology is useful for them, they will eventually use it. This set of findings is aligned with previous studies conducted by Venkatesh and Davis (2000).

H3: The standardized path coefficient between perceived ease of use and usage intentions was 0.218 at t-value equals to $3.876^{* * *}$. Perceived ease of use has significantly influence on usage Intentions. Thus, H3 was supported. It can be described that if the system that bank provides to customer is easy to use which customers do not need to learn new thing that is complicated, then they will have intention to adapt it. This set of findings is aligned with previous studies conducted by Davis (1989).

H4: The standardized path coefficient between perceived credibility and usage intentions was 0.059 at t-value equals to 0.970 . Perceived credibility has no significantly influence on usage Intentions. Thus, H4 was not supported. The study can conclude that the perceived credibility is not effected in usage intention on cardless ATM which they do not concern that this service is reliable or not.

H5: The standardized path coefficient between the amount of information and usage intentions was 0.252 at $\mathrm{t}$-value equals to $4.298 * * *$ ). The amount of information has significantly influence on usage intention. Therefore, H5 was supported. It can be assumed that the knowledge and understanding of the program's structure lead them to use the system. This set of findings is aligned with previous studies conducted by Sathye (1999).

\subsection{Direct, Indirect and Total Effects of Relationships}


In this study, AMOS program was applied to explain the influences of one variable on another into direct, indirect and total effects. The meaning of direct effect is there are no mediating variables between independent and dependent variables. On the contrary, the indirect effect means that there is at least one mediating variable between independent and dependent variable. The total effect is direct effect combining with indirect effects (Ajren, 2002). As shown in Table 8, this summarizes the effects for the general structural equation model with latent variables. In addition, Figure 2 shows the structural equation model of this research.

Table 8. Direct, Indirect and Total Effects of Relationships

\begin{tabular}{|c|c|c|c|c|c|}
\hline $\begin{array}{c}\text { Dependent } \\
\text { Variables }\end{array}$ & Effect & $\begin{array}{c}\text { Perceived } \\
\text { Usefulness }\end{array}$ & $\begin{array}{c}\text { Perceived } \\
\text { Ease of use }\end{array}$ & $\begin{array}{c}\text { Perceived } \\
\text { Credibility }\end{array}$ & $\begin{array}{c}\text { The Amount of } \\
\text { information }\end{array}$ \\
\hline $\begin{array}{c}\text { Perceived } \\
\text { Usefulness }\end{array}$ & DE & - & $0.563^{* * *}$ & - & - \\
\hline & $\mathrm{IE}$ & - & - & - & - \\
\hline & $\mathrm{TE}$ & - & $0.563^{* * *}$ & - & - \\
\hline & $\mathrm{R}^{2}$ & \multicolumn{5}{|c|}{0.317} & $0.252^{* * *}$ \\
\hline $\begin{array}{c}\text { Usages } \\
\text { Intention }\end{array}$ & $\mathrm{DE}$ & $0.371^{* * *}$ & $0.218^{* * *}$ & 0.059 & - \\
\hline & $\mathrm{IE}$ & - & 0.209 & - & $0.252^{* * *}$ \\
\hline & $\mathrm{TE}$ & $0.371^{* * *}$ & $0.426^{* * *}$ & 0.059 & \\
\hline & $\mathrm{R}$ & \multicolumn{5}{|c|}{0.525} \\
\hline
\end{tabular}

Note: $D E=$ Direct Effect, IE = Indirect Effect, TE = Total Effect $(D E+I E), * * *=p<0.05$ Source: Author.

Figure 2. The Structural Equation Model Results

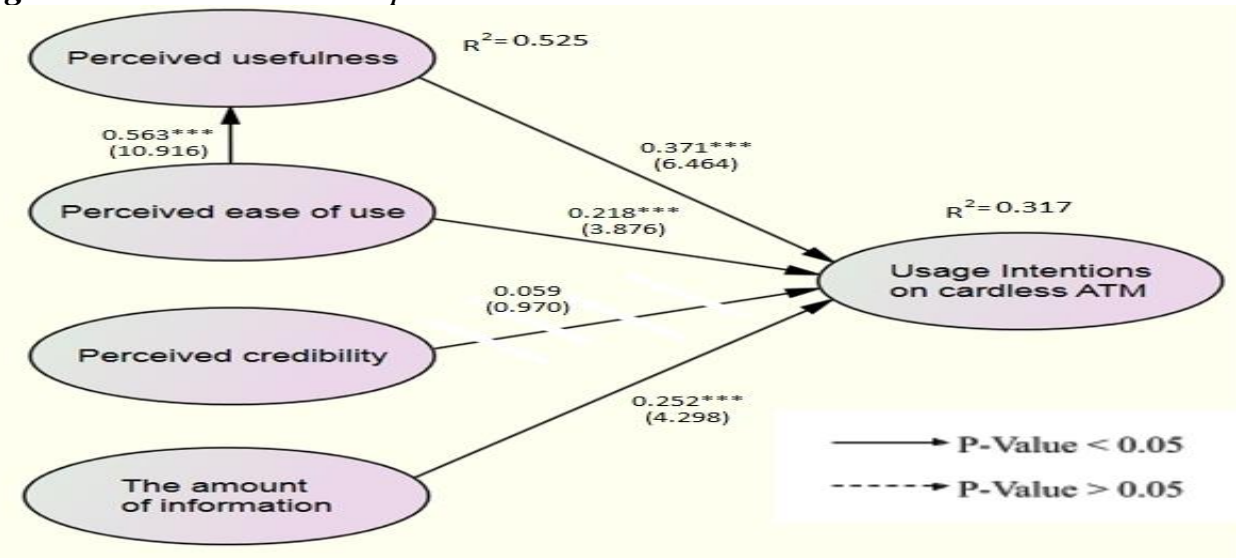

Source: Author.

The result from Table 8 can be summarizing as followed:

Perceived Usefulness: The significant direct effect of perceived ease of use on perceived usefulness was 0.563 with no indirect affect. Therefore, the direct affects are the same with total effects. 
Usage Intention: There are three variables that have direct effect on Usage Intention. Firstly, the significant direct effect of perceived usefulness on usage intention was 0.371. Secondly, the significant direct effect of perceived ease of use on usage intention was 0.218 . Thirdly, the significant direct effect of the amount of information on usage intention was 0.252 .

However, there was one insignificant direct effect that is perceived credibility on usage intention in which the result is 0.059 . Then for the significant indirect effect of perceived ease of use on usage Intention was 0.209.

To summarize, perceived ease of use has the most significant influence on Cardless Automatic Teller Machine (ATM) usage intention (0.426) followed by perceived ease of use on usage intention (0.371), and the amount of information on usage intention stands at 0.252 .

\section{Conclusion}

This research aims to investigate factors influencing of cardless ATM usage Intention. The conceptual framework was adapted from research of an analysis of intention to use mobile credit card (Ajren, 2007). The research included perceived usefulness, perceived ease of use, perceived credibility, the amount of information and usage intention. A total 400 questionnaires were distributed to target respondents who are Thai bank customer who normally withdrawn cash via ATM but never had experience with cardless ATM service. The findings were evaluated via CFA to check the model's validity and reliability. In additional, to examine the influence between variables, Structural Equation Model (SEM) was applied.

Among all the factors in same dependent variable as usage intention, it was confirmed that perceived usefulness has the most direct influence. Because of many benefits of cardless ATM that banks offer to customer so that they can use this service free of charge as opposed to ATM card or debit card for which they need to pay at least 200 THB a year. Another benefit is customers do not need to hold for plastic cards which is very convenience for them when they are outside and forget to bring a card. Moreover, the customer can reduce a risk of losing such card. Thus customer perceives that these benefits are useful for them and they are willing to use cardless ATM. The next factor is related to perceived ease of use. Since, the cardless ATM is easy for customers, for which the function was easy to learn and understand and also customers can use it via mobile banking which is convenient for those who use the application. The last factor is the amount of information that this study supports (Pikkarainen et al., 2004). Therefore, this study indicated that bank provided many information for customers before they decide to use it and customers can find information from many channels such as, Internet, social media and the bank' branch. 
Further analysis has shown that perceived ease of use has also a direct influence on perceived usefulness (Cheong and Park, 2005). This study has shown that customers think that the application will help them if they believe it's easy to understand. They will not accept the application even it benefits them because they think that it is hard for them to learn and they may not have the ability to understand and use it

As part of the study implications, it provides important information for practitioners (i.e. banks), academicians (i.e. lecturers) and bank customers. On the part of the practitioners, bank management should establish a favourable confidence in terms of utility and ease of use of their Cardless ATM in the consumer. This could be achieved by arranging a cardless ATM training course to improve the comfort of customers with the device. In addition, bank management can provide a mini guide providing information on the cardless ATM and accessible at bank branches all the time. From the academic side, this study should be able to increase the cardless ATM knowledge base, thus encouraging further future research in the same area. In case of bank customers, this banking gadget can provide more options for withdrawing transactions, in addition to cash and a conventional withdrawal card.

\section{Recommendations}

Findings of this study indicate that usage intention on cardless ATM rely on perceived usefulness, perceived ease of use and the amount of information. Both perceived usefulness and perceive ease of use strongly influence usage Intention.

Therefore, the research provides recommendations to those variables to develop application to apply in cardless ATM service as it should link with the phone number of customers. When the customer withdraws transaction via application, a Short Message Service (SMS) will send to the customer immediately to show how much they withdraw and the remaining amount of balance in account. Therefore, the application should be customized for customers so they can adjust the features of application by adding the favorite service that always use in the application on the first page of application and can determine the amount of money and number of time in withdrawing money in each day to protect the uncertainties. Moreover, the application should provide a chat box for customers to contact directly with the staff when they want.

The bank should increase and improve the capabilities of the application to make it easier and effective. As this service requires for QR code or password (Difference in each bank) to log-in or scan it to the ATM when customers conduct transactions which may be complicated and loss of time for customers. Therefore, in future the bank should update facial scan recognition instead of increasing convenience and ease of ease for them. Customers can order to withdraw from mobile banking and withdraw by facial scan ID within 24 hours which it very useful for people who are in urgent time and a lot of baggage. In addition, when any problem occurs in the application, the bank should provide an easy way for customers to solve the problem 
which they may solve by themselves or the bank resolve it for them without going to the bank. Moreover, the bank should ensure that cardless ATM service in mobile application is user-friendly for different age of customers because people who have been using mobile application to have variety of age range. Elderly customers are the customer group that needs to be the most concerned because most of them have low technology skills.

In terms of the amount of information, the bank should provide necessary information to customers to make intention of use with them. The information could be available in many channels to create awareness of customers such as, application, social media or website. In terms of application (mobile banking) it, should provide information on the method of using for customers to make them easy to understand when they use for the first-time. Thus, in terms of social media the bank should review this service by creating video that present about the information of services such as, what is this service about, how to use it and benefit and what are the limitations of it, in which the video could be used by an influencer to attract new customers to come and use the service. The video can be promoted on Facebook, YouTube and Instagram. In the same way, on bank's website the information should be available. Moreover, call centers are one of the important information centers for customers when they have a questions before deciding to use it which call centers must answer every question about cardless ATM service to increase usage intention.

\section{Limitations and Future Research Directions}

This research composes with important insights about factors influencing usage intention in cardless ATM. However, there are certain limitations of this study which should be applied to further research. Firstly, the target respondent of this study is focused on people who have never experienced cardless ATM. To collect data from the sample group, researcher need to explain and show the basic operating methods to make clearer understanding. However, even if they have information from the researchers but still do not have in depth clearance, such as people who have experienced directly with this service and also few people who have refused to give data because they are not sure that they have the right understanding about information regarding this this service.

Therefore, in terms of further study, the target respondent should be changed to be Thai bank customers who have experience using cardless ATM to analyze data from this group and compare the results. Secondly, there are a few numbers of factors in this study for which other factors are not included in the study for which it may not be covering all of the measurables that influence to usage intention on cardless ATM. Therefore, future study should add more factors such as perceived financial cost, perceived self-efficacy and perceive security to make more understanding from target respondents. Lastly, there is no moderating variables in this study, so further study should be come up with moderating variables such as 'attitude'. 


\section{K. Phothikitti}

\section{References:}

Alalwan, A.A., Dwivedi, Y.K., Rana, N.P. 2017. Factors influencing adoption of mobile banking by Jordanian bank customers: Extending UTAUT2 with trust. International Journal of Information Management, 37(3), 99-110. https://doi.org/10.1016/j.ijinfomgt.

Ajzen, I. 2002. Perceived behavioural control, self-efficacy, locus of control, and thetheory of planned behaviour. Journal of Applied Social Psychology, 32, 665-683.

Ajzen, I., Fishbein, M. 1980. Understanding Attitudes and Predicting Social Behaviour. Prentice-Hall, Englewood Cliffs, NJ.

Bangkok Post. 2019a. Credit Card Pushes Chip Based Cash Cards. https://www.bangkokpost.com/business/1752529/central-bank-pushes-chip-basedcash-cards.

Bangkok Post. 2019b. Digital Payments on the Rise. https://www.bangkokpost.com/business/1629311/digital-payments-on-the-rise.

Browne, M.W., Cudeck, R. 1993. Alternative ways of assessing model fit. In K.A. Bollen, J. S. Long (Eds.), Testing structural equation models, 136-162.

Cheong, J.H., Park, M.C. 2005. Mobile internet acceptance in Korea. Internet Research, $15(2), 125-140$.

Davis, F.D. 1986. A Technology Acceptance Model for Empirically Testing New End-User Infor-mation Systems: Theory and Results. Doctoral dissertation, MIT Sloan School of Management, Cambridge, MA.

Davis, F.D., Bagozzi, R.P., Warshaw, P.R. 1992. Extrinsic and intrinsic motivation to use computers in the workplace. Journal of Applied Social Psychology, 22(14), 11111132.

Davis F.D. 1993. User acceptance of information technology: system characteristics, user perceptions and behavioural impacts. Int. J. Man. Mach. Stud., 38, 475-487.

Davis, F.D. 1989. Perceived usefulness, perceived ease of use, and user acceptance of information technology. MIS Quarterly, 13(3), 319-339.

Drewniak, Z., Posadzińska, I. 2020. Learning and Development Tools and the Innovative Potential of Artificial Intelligence Companies. European Research Studies Journal, 23(2), 388-404. DOI: 10.35808/ersj/1599.

Elkhani, N., Soltani, S., Ahmad, N. 2014. The effects of transformational leadership and ERP system self-efficacy on ERP system usage. Journal of Enterprise Information Management, 27(6), 759-785.

Fishbein, M., Ajzen, I. 1975. Belief, Attitude, Intention, and Behaviour: An Introduction to Theory and Research. Reading, MA, Addison-Wesley.

Guriting, P., Ndubisi, N.O. 2006. Borneo online banking: Evaluating customer perceptions and behavioural intention. Man. Res. News. 29(1/2), 6-15.

Hair, J.F., Anderson, R.E., Tatham, R.L., Black, W.C. 2010. Multivariate Data Analysis (6 $6^{\text {th }}$ edition). Upper Saddle River, NJ, Prentice Hall, 137-142.

Hair, J., Black, W., Babin, B., Anderson, R., Tatham, R. 2006. Multivariate Data Analysis, $6^{\text {th }}$ ed. Pearson Education, Harlow.

Howard, J., Moore, W. 1982. Changes in consumer behaviour over the product life cycle. In Tushman, M. and Moore, W.L. (Eds), Readings in the Management of Innovation. Pitman, Boston, MA, p. 128.

Al-Fahim, H.N. 2012. Factors affecting the adoption of internet banking amongst IIUM students: A structural equation model approach. Journal of internet banking and commerce, 17(3), 1-14. 
$\mathrm{Hu}$ and Bentler. 1999. Cut-off criteria for fit indexes in covariance structure analysis: Conventional criteria versus new alternatives. Structural Equation Modelling, 6(1), $1-55$.

Howcroft, B., Hamilton, R., Hewer, P. 2002. Consumer attitude and the usage and adoption of home-based banking in the United Kingdom. International Journal of Bank Marketing, 20(3), 111-121.

Kesharwani, A., Bisht, S.S. 2012. The impact of trust and perceived risk on internet banking adoption in India: An extension of the Technology Acceptance Model. International journal of bank marketing, 30(4), 303-322.

Kleijnen, M., Wetzels, M., de Ruyter, K. 2004. Consumer acceptance of wireless finance. Journal of Financial Services Marketing, 8(3), 206-217.

Kline, P. 1994. An easy guide to factor analysis. New York, Routledge.

Luarn, P., Lin, H.H. 2004. Toward an understanding of the behavioural intention to use mobile banking. Elsevier.

Mathwick, C., Malhotra, R.N.K. 2001. The effect of dynamic retail experiences on experiential perceptions of value: An Internet and catalog comparison. J. Retailing, 78(1), 51-60.

Marsh, H.W., Hau, K.T., Wen, Z. 2004. In search of golden rules: Comment on hypothesistesting approaches to setting cutoff values for fit indexes and dangers in overgeneralizing Hu and Bentler's (1999) findings. Structural equation modelling, 11(3), 320-341.

Pikkarainen, T., Pikkarainen, K., Karjaluoto, H., Pahnila, S. 2004. Consumer acceptance of online banking: an extension of the technology acceptance model. Internet Research, 14(3), 224-235.

Sachpazidu-Wojcicka, K. 2020. Open innovation process via technology transfer and organizational innovation. European Research Studies Journal, 23(1), 52-61. DOI: $10.35808 / \mathrm{ersj} / 1535$.

Safeena, R., Date, H., Kammani, A., Hundewale, N. 2012. Technology adoption and Indian consumers: study on mobile banking. International Journal of Computer Theory and Engineering, 4(6), 1020-1024.

Sathye, M. 1999. Adoption of internet banking by Australian consumers: an empirical investigation. International Journal of Bank Marketing, 17(7), 324-334.

Suhr, D. 2006. Exploratory or Confirmatory Factor Analysis? Proceedings of the 31st Annual SAS? Users Group International Conference. Cary, NC, SAS Institute Inc., Paper Number, 200-31.

Tavakol, M., Dennick, R. 2011. Making sense of Cronbach's alpha. International Journal of Medical Education, 53-55.

Venkatesh, V., Thong, J.Y.L., Xu, X. 2012. Consumer acceptance and use of information technology: Extending the Unified Theory of Acceptance and use of technology. MIS Quarterly, 36(1), 157-178.

Venkatesh, V. 2000. Determinants of perceived ease of use: integrating control, intrinsic motivation, and emotion into the technology acceptance model. Info. Syst. Res. 4(4), 342-365.

WU, J.H., Wang, S.C. 2005. What drives mobile commerce? An empirical evaluation of the revised technology acceptance model. Information \& Management, 42, 719-729.

Wang, Y.S., Wang, Y.M., Lin, H.H., Tang, T.I. 2003. Determinants of user acceptance of internet banking: an empirical study. International Journal of Service Industry Management, 14(5), 501-519. 